This authors' personal copy may not be publicly or systematically copied or distributed, or posted on the Open Web, except with written permission of the copyright holder(s). It may be distributed to interested individuals on request.

\begin{tabular}{c|c|c}
\hline \hline $\begin{array}{c}\text { Vol. 558: 153-158, 2016 } \\
\text { doi: } 10.3354 / \mathrm{meps} 11869\end{array}$ & $\begin{array}{c}\text { MARINE ECOLOGY PROGRESS SERIES } \\
\text { Mar Ecol Prog Ser }\end{array}$ & Published October 25 \\
\hline \hline
\end{tabular}

\title{
NOTE
}

\section{Fast-spreading green beds of recently introduced Halimeda incrassata invade Mallorca island (NW Mediterranean Sea)}

\author{
Josep Alós ${ }^{1,2, *}$, Fiona Tomas ${ }^{1,3}$, Jorge Terrados ${ }^{1}$, Heroen Verbruggen ${ }^{4}$, \\ Enric Ballesteros ${ }^{5}$ \\ ${ }^{1}$ Instituto Mediterráneo de Estudios Avanzados, IMEDEA (CSIC-UIB). C/ Miquel Marqués 21, 07190, Esporles, Illes Balears, \\ Spain \\ ${ }^{2}$ Department of Biology and Ecology of Fishes, Leibniz-Institute of Freshwater Ecology and Inland Fisheries, \\ Müggelseedamm 310, 12587 Berlin, Germany \\ ${ }^{3}$ Department of Fisheries and Wildlife, Oregon State University, OR, USA \\ ${ }^{4}$ School of BioSciences, University of Melbourne, Victoria 3010, Australia \\ ${ }^{5}$ Centre d'Estudis Avançats de Blanes (CEAB-CSIC), C/ Accés Cala Sant Francesc 14, 17300, Girona, Spain
}

\begin{abstract}
Mediterranean marine biodiversity is undergoing a tropicalization process. We present the first record and spread dynamics of the tropical green seaweed Halimeda incrassata (Bryopsidales, Chlorophyta) from the Mediterranean Sea. Plants were observed at 2 sites off Mallorca island (NW Mediterranean), and species identification was confirmed molecularly. Since the first observation of this alien seaweed in 2011, it has spread rapidly in the shallow subtidal habitat of a marine protected area located in Palma Bay, which has a depth of up to ca. $20 \mathrm{~m}$. By 2015, this species spread by a factor of 6.75 and extended to an area of $2.7 \mathrm{~km}^{2}$, covering a total of $41 \%$ of the monitored area. The dynamics of the invasion suggest rapid colonization and establishment and spreading of the species through shallow sedimentary and rocky habitats. H. incrassata has the potential to strongly alter the ecosystem services and functioning of shallow Mediterranean habitats. We encourage authorities to pay attention to the spread of this alien seaweed at larger scales and determine the positive and negative effects of the invasion in order to facilitate research-driven decision making.
\end{abstract}

KEY WORDS: Alien species · Fisheries · Mediterranean Sea · Tropicalization · Sediments · tufA gene

Resale or republication not permitted without written consent of the publisher

\section{INTRODUCTION}

Redistribution of species ranges across the globe has dramatically increased in the last century (García Molinos et al. 2016). Marine ecosystems are particularly vulnerable to the arrival of new species, with rates of spread of marine organisms being over an order of magnitude higher than for terrestrial species (Poloczanska et al. 2013). Global warming and ship- ping activities are facilitating the tropicalization of temperate marine communities by promoting the range expansions of tropical species to higher latitudes (Vergés et al. 2014) and by enhancing the introduction, invasion and spread of non-native species (Rius et al. 2014).

The Mediterranean Sea is a global hotspot of marine species invasions (Galil et al. 2014). Many nonnative species of tropical origin have colonized this 
sea, leading to a tropicalization of its biodiversity (Bianchi 2007, Zenetos et al. 2010). Introduction of invasive seaweeds, such as Caulerpa taxifolia (M. Vahl) C. Agardh, are prime examples of tropical nonnative species that have raised scientific and public awareness of the potential dangers to native Mediterranean biodiversity (Hoffman 2014).

Halimeda incrassata (J. Ellis) J. V. Lamouroux is one of the most common species of the genus Halimeda growing on tropical sandy-bottom habitats (Verbruggen et al. 2006). H. incrassata beds are major producers of organic matter and calcium carbonate $\left(\mathrm{CaCO}_{3}\right)$ in tropical areas and contribute notably to ecosystem functioning by generating sediment habitat harbouring organisms that are a food source for fish from the surrounding ecosystems, including mangroves, seagrass beds and sand-patches on outer reef slopes (Wefer 1980, Verbruggen et al. 2006).

$H$. incrassata is naturally distributed in the tropical western Atlantic and Indo-Pacific Oceans (Guiry \& Guiry 2016). In 2005 it was reported for the first time on the island of Madeira (NE Atlantic) (Wirtz \& Kaufmann 2005). The goals of this paper are to report the first record of this species from the Mediterranean Sea and describe its spread dynamics. We use a combination of morphological observations and a molecular study to establish the identity of the species as well as habitat surveys to map its new distribution. We discuss plausible introduction mechanisms, potential positive and negative effects of the invasion, and which decision-making actions should be considered.

\section{MATERIALS AND METHODS}

\section{First records and identification of Halimeda incrassata}

The Marine Protected Area of Palma Bay (MPAPB) is located along the south-western shore of Mallorca island (NW Mediterranean, Fig. 1A). This nature reserve, established in 1982, covers an open water area which extends from the shore to a depth of $30 \mathrm{~m}$ (Alós \& Arlinghaus 2013). It is dominated by a mixture of Posidonia oceanica seagrass beds and rocky and sedimentary habitats (Fig. 1C). In 2011, we detected the presence of $H$. incrassata in 2 sites of the MPAPB while using scuba: Cala Blava ( $\mathrm{CB}$; Fig. $1 \mathrm{~A})$ and in a shallow zone in the south part of the MPAPB, where fishing with some restrictions is permitted (partial MPA) and a popular recreational fishery of the pearly razorfish Xyrichtys novacula is practiced (Fig. 1B,C and see Alós et al. 2012). In addition, we also found H. incrassata in 2014 at the western part of Palma Bay, in Portal Vells (PV), where depths ranged between ca. 1 and $7 \mathrm{~m}$ (Fig. 1A).

Representative specimens from the MPAPB (Fig. 1A) were collected in 2014, preserved in 96\% ethanol and identified based on external appearance, anatomical observations and DNA sequencing. Morphological features were compared to those published in Hillis-Colinvaux (1980) and Verbruggen et al. (2006). DNA extraction and amplification of the tufA gene of the individuals was carried out following Cremen et al. (2016). Sequences were compared to established datasets of reference sequences (Verbruggen et al. 2009). Sequences of available Halimeda species were clustered with UPGMA in Geneious v.8.0.4 using a Hasegawa-Kishino-Yano model of sequence evolution.

\section{Temporal dynamics of the invasion in the MPAPB}

Several underwater video cameras were deployed every August from 2011 to 2015 in a different number of randomly generated geographic points within a monitored area of the MPAPB (Table 1, Fig. 1B) in order to measure the distribution of Halimeda incrassata (Fig. 1B). Videos were analysed, and the presence or absence of $H$. incrassata was recorded at each geographic point/coordinate (latitude and longitude) surveyed. The distribution of $H$. incrassata and its area of invasion within the monitored area (6.4 km² ; Fig. 1C) were estimated using spatial analysis tools. We first assessed the spatial autocorrelation of the data using Moran's I autocorrelation index (Table 1). Results demonstrated that data were spatially autocorrelated (Table 1 ). To estimate the total extension (in $\mathrm{km}^{2}$ ) invaded each year, we therefore used conventional linear interpolation (ordinary kriging) based in a grid of cells of $50 \times 50 \mathrm{~m}$ to predict the presence or absence of $H$. incrassata at the monitored site (Table 1). All analyses were performed in $R(R$ Core Team 2015).

\section{RESULTS}

Morphological and molecular results conclusively show that the new alien species found in Palma Bay is Halimeda incrassata. Plants are erect and up to $10 \mathrm{~cm}$ high and composed of grass-green segments (Figs. 1B \& 2A). The great majority of seg- 

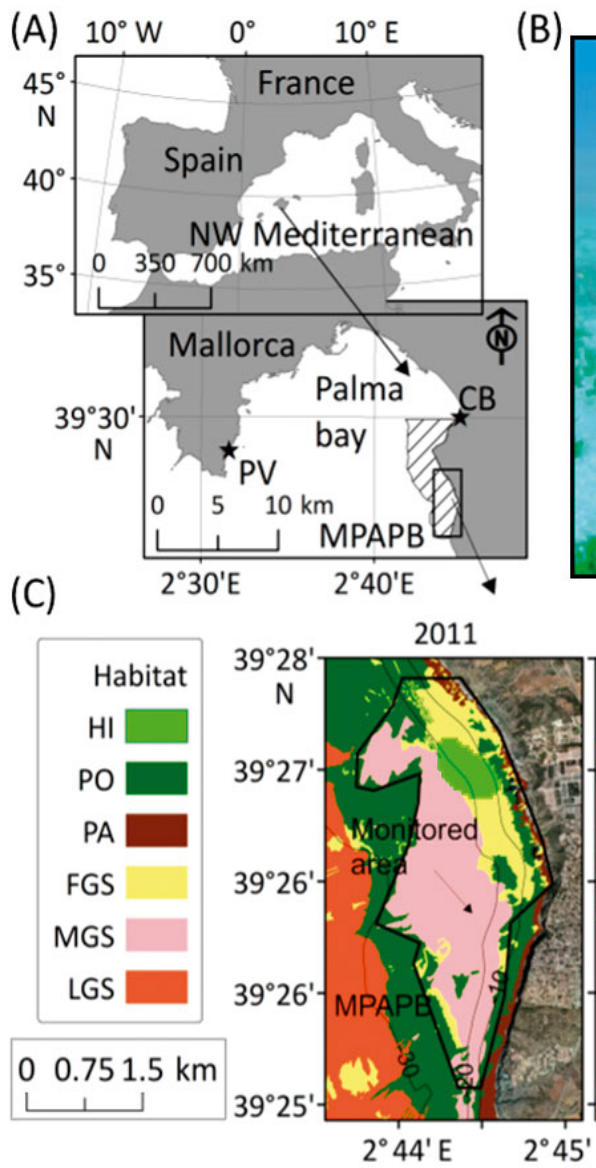

(B)

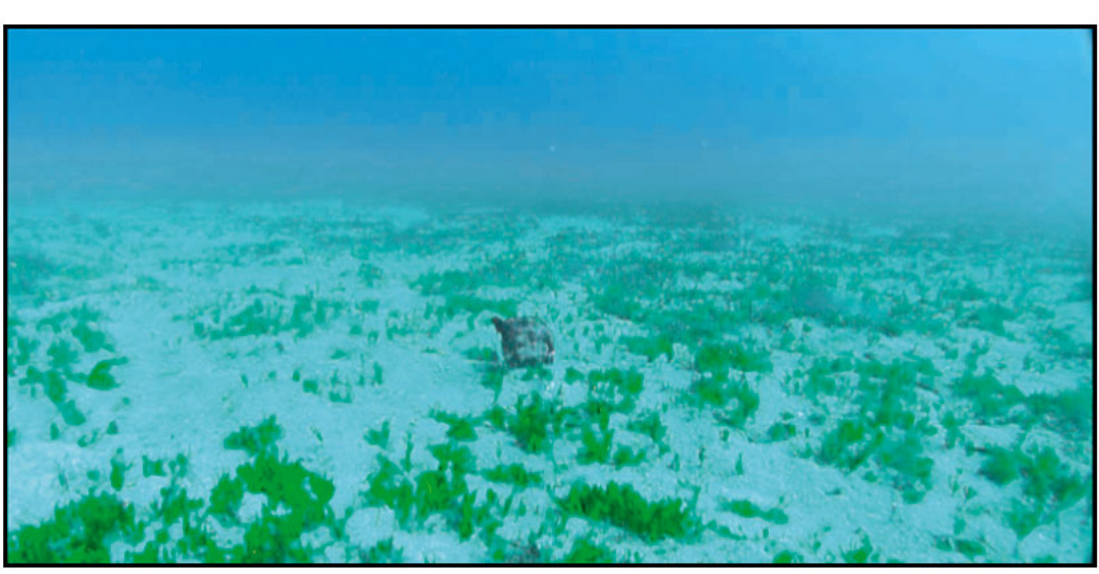

2013

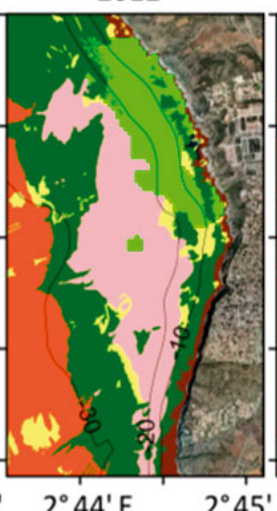

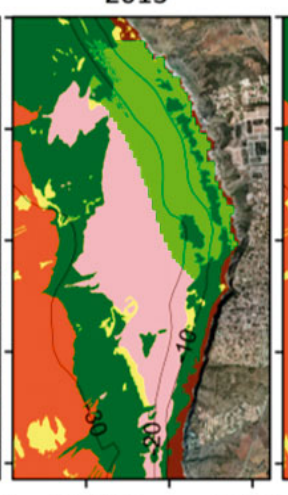
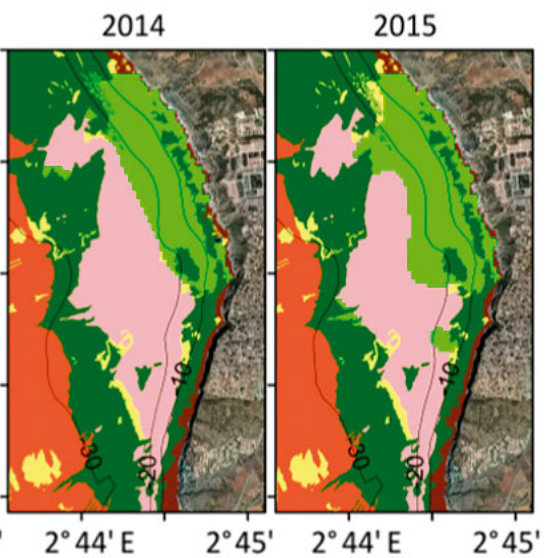

Fig. 1. Location and dynamics of the invasion of Halimeda incrassata in the waters of Mallorca island. (A) Two areas in the waters of Palma Bay where we report the presence of $H$. incrassata: Portal Vells (PV) and the Marine Protected Area of Palma Bay (MPAPB, striped area). Highlighted in the MPAPB: Cala Blava (CB) and the fishery zone of pearly razorfish (rectangle). (B) Still frame of a video recording presence of the alien species H. incrassata. (C) Southern part of the MPAPB where the presence of the invasive species has been identified and evaluated (monitored area outlined in black as indicated by arrow in first panel). Maps show area covered by H. incrassata (HI), the Posidonia oceanica seagrass bed (PO), photophilic algae habitats (PA), fine- (FGS), medium- (MGS), and large-grain (LGS) sand. The native habitat cartography was developed by the local Government (Govern de les illes Balears) under the Posidonia-LIFE project (http://lifeposidonia.caib.es)

Table 1 Temporal dynamics of the invasion of Halimeda incrassata at the Marine Protected Area of Palma Bay (MPAPB, Mallorca Island). Number of locations sampled (n) in the monitored site, percentage of points where $H$. incrassata was detected and the area invaded (in $\mathrm{km}^{2}$ and as percentage of the monitored area per year). The observed and expected Moran's I autocorrelation index $\left(\mathrm{MI} I_{\mathrm{o}}\right.$ and $\left.\mathrm{M} I_{\mathrm{e}}\right)$ plus the standard deviation (SD) were used to test the existence of spatial autocorrelation among the sampled points. $p<0.05$ suggested the existence of spatial autocorrelation

\begin{tabular}{|ccccccccc|}
\hline Year & $\mathrm{n}$ & $\begin{array}{c}\text { Presence } \\
(\%)\end{array}$ & \multicolumn{2}{c}{$\begin{array}{c}\text { Area invaded } \\
\left(\mathrm{km}^{2}\right)\end{array}$} & $\mathrm{M} I_{\mathrm{o}}$ & $\mathrm{M} I_{\mathrm{e}}$ & $\mathrm{SD}$ & $\mathrm{p}$ \\
\hline 2011 & 65 & 13.8 & 0.4 & 6.2 & 0.20 & -0.02 & 0.02 & $<0.001$ \\
2012 & 94 & 35.1 & 1.9 & 28.9 & 0.30 & -0.01 & 0.02 & $<0.001$ \\
2013 & 41 & 39.0 & 2.6 & 40.8 & 0.13 & -0.03 & 0.03 & $<0.003$ \\
2014 & 85 & 29.4 & 2.3 & 36.1 & 0.32 & -0.01 & 0.02 & $<0.001$ \\
2015 & 47 & 40.4 & 2.7 & 41.1 & 0.34 & -0.02 & 0.03 & $<0.001$ \\
\hline
\end{tabular}

ments are flat and are diamondshaped or round. Segment dimensions are $2.1-4.5 \mathrm{~mm}$ in width and 2.1-3.7 $\mathrm{mm}$ in height and vary from being slightly narrower than they are high to being nearly $1.5 \times$ wider than they are high. Cylindrical segments and larger tri-lobed segments are present near the base of the plant. Medullar siphons fuse into a single unit at the nodes, with pores connecting adjacent siphons. The cortex is composed of 2 (rarely 3) layers of utricles (Fig. 2B). Peripheral utricles measure 55-70 $\mu \mathrm{m}$ in width by $50-70 \mu \mathrm{m}$ in height and are 
A

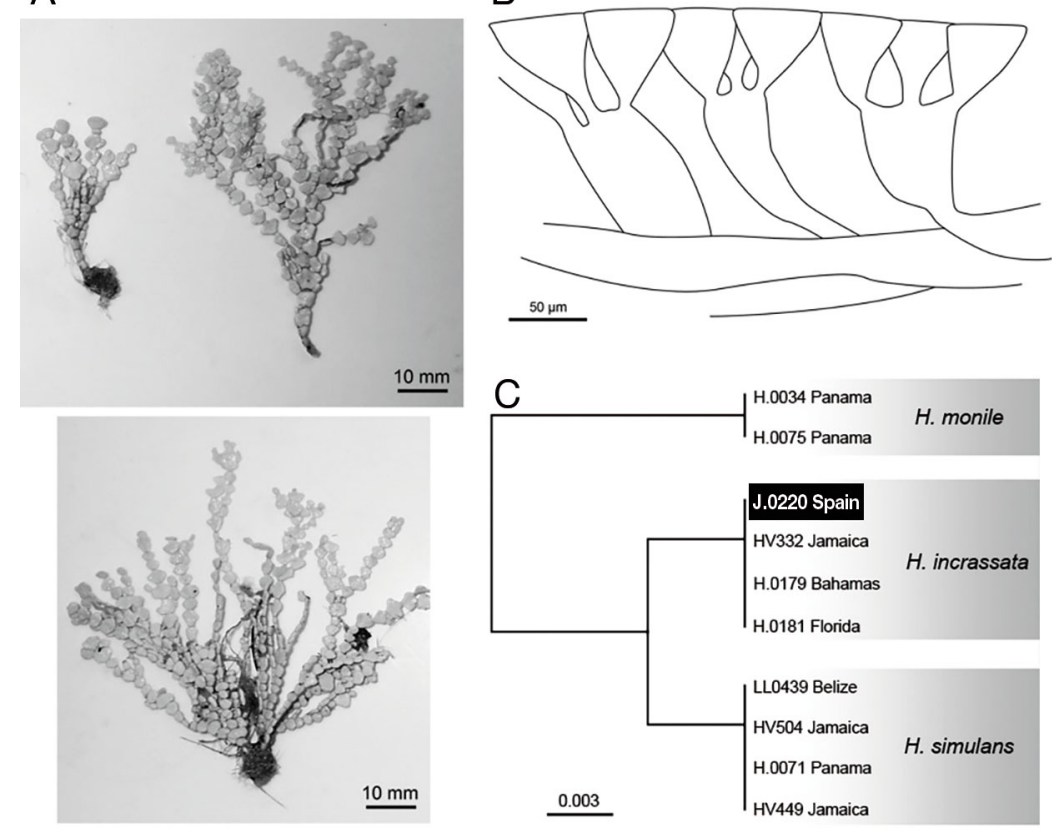

Fig. 2. Habit, inner morphology and molecular characteristics of Halimeda incrassata plants found in the waters of Mallorca Island. (A) Habit of specimens collected in Palma Bay. (B) Cortex composed of 2 layers of utricles. (C) Cluster in UPGMA analysis of the tufA sequence of the Mediterranean plant and specimens collected from the tropical western Atlantic medium-grain sand habitats was observed afterwards. These results, plus the images collected in CB (Fig. S1), suggest that most of the shallow waters of the MPAPB are probably invaded by this tropical species.

\section{DISCUSSION}

This study reports the first record of the tropical green seaweed Halimeda incrassata from the Mediterranean Sea. Morphological features were in high agreement with those published in the literature (Hillis-Colinvaux 1980, Verbruggen et al. 2006). Anatomical observations revealed that the Mediterranean plants have tiny segments with 2-3 layers of utricles in contrast to the plants typically seen in Caribbean waters, which usually have bigger segments with 3-5 layers (Hillis-Colinvaux 1980, Littler \& Littler 2000, Verbruggen et al. 2006). Small segments have been also observed in the population described from Madeira Island always about as wide as they are high. Secondary utricles measure 40-60 $\mu \mathrm{m}$ in width and 100-130 $\mu \mathrm{m}$ in height and generally carry 3 peripheral utricles. The tufA sequence of the Mediterranean plant is identical to those obtained from tropical western Atlantic specimens and fell within the $H$. incrassata cluster in UPGMA analysis (Fig. 2C).

Since the first observations in 2011 and proper identification in 2015 of $H$. incrassata in the MPAPB, in August of 2015 (the last time we visited the CB site), we have observed many beds composed of this species in CB while snorkelling (Fig. S1 in the Supplement at www.int-res.com/articles/suppl/m558 p153_supp.pdf). Analysis of the spread of $H$. incrassata, based on underwater videography, demonstrated the rapid colonization and fast spread of this alien species (Table 1, Fig. 1B,C) and indicated that it has become invasive. In 2011, $0.4 \mathrm{~km}^{2}$ of the total monitored area of $6.4 \mathrm{~km}^{2}$ was invaded, i.e. $6.2 \%$ of the total area covered (Table 1). By 2015, H. incrassata covered $41 \%$ of the monitored zone, occupying most of the fine-grain sand of the area (Fig. 1B,C, Table 1). The overall invaded area has not changed much since 2013 (Fig. 1C), which suggests a rapid colonization of the fine-grain sand available habitat, while no dispersal to the deeper ( $>20 \mathrm{~m}$ depth) and
(Wirtz \& Kaufmann 2005). Molecular results confirmed that the new invasive species is $H$. incrassata. The oligotrophic waters of Mallorca island have probably facilitated the invasion of $H$. incrassata in the Mediterranean Sea, and it is expected that this species will spread due to global warming and the absence of its specific native consumers, i.e. the main known predator Sparisoma radians (Targett et al. 1986) is not present in the Mediterranean.

Plausible pathways of the introduction of $H$. incrassata into the Mediterranean Sea are the aquarium industry and/or shipping. $H$. incrassata is commonly used to decorate public and private aquaria. Therefore, the occurrence in the Mediterranean could have been due to accidental release from aquaria near the area studied. Shipping is the main vector of introduction of exotic seaweeds in the Mediterranean Sea (Zenetos et al. 2010, Hoffman 2014). Therefore, it is possible that $H$. incrassata arrived through ships that cover the route from the Caribbean to the Mediterranean. However, the introduction of the species through ballast waters of commercial ships seems unlikely, since this alga does not have planktonic spores and its gametes and zygotes are short-lived. Plants and/or fragments could have reached Mallorca attached to anchors of 
recreational yachts. This hypothesis would be consistent with the recent observations of $H$. incrassata in Madeira (Wirtz \& Kaufmann 2005). Further investigation is needed to identify the mechanism that caused this introduction.

The presence of $H$. incrassata in the island of Mallorca is far from being anecdotal. The monitored invaded area has increased by a factor of 6.75 in $5 \mathrm{yr}$ (from $0.4 \mathrm{~km}^{2}$ in 2011 to $2.7 \mathrm{~km}^{2}$ in 2015). However, this dynamic seems to be non-linear as spreading has decelerated (Fig. 1C). Two main factors could explain the above phenomenon. First, deeper areas (below $20 \mathrm{~m}$ depth, see Fig. 1C) with low irradiance levels and cold water may not be adequate for successful establishment of the species (Wefer 1980). Second, the southwest part of the monitored area is covered by sediment composed of medium-sized grains, and the proper fixation of the plants in this sediment may be difficult. We need more accurate data to fully understand the exact mechanisms driving the spread of this species in Mallorca. In any case, our data suggests a great potential for fast-spreading in the shallow sedimentary habitats, which is not unexpected considering the fast growth and asexual spread of this species (Wefer 1980, Multer 1988, Van Tussenbroek \& Van Dijk 2007).

$H$. incrassata is one of the most important producers of organic matter and $\mathrm{CaCO}_{3}$ in tropical sediments (Wefer 1980). It forms patchy beds (Multer 1988), has a high growth rate (Wefer 1980, Van Tussenbroek \& Van Dijk 2007), interacts with native seagrasses (Davis \& Fourqurean 2001) and is highly protected against predators (Targett et al. 1986). Therefore, the invasion of this species in the Mediterranean Sea threatens the structure and functioning of native ecosystems. We recommend that the impact of $H$. incrassata on sediment dynamics, interactions with native seaweeds and the native seagrass Posidonia oceanica, and food-web changes be studied in detail. Moreover, shallow sedimentary Mediterranean habitats provide important ecosystem services which could be impacted by this invasion. For example, the invasion could change the distribution of the pearly razorfish, which is an important recreationally exploited species (Alós et al. 2012). Authorities are, therefore, encouraged to develop a comprehensive socio-ecological approach to this problem and take action in order to study and reduce the consequences of this invasion. The recent guidances by Ojaveer et al. (2014) for proper management of alien species provide an appropriate context for developing this task.
Acknowledgements. The data used for this study was obtained through the project REC2 (CTM2011-23835) and a Marie Curie grant (grant no. 327160). We thank Antoni Grau (Govern de les illes Balears) for supporting and authorizing the study in the MPAPB and Rosario Rosselló and Chiela Cremen for their help. J.A. was supported by a JdC postdoc (FJCI-2014-21239) and F.T. by a RyC grant (MINECO). The Verbruggen lab received funding from the ARC (FT110100585) and the ABRS (RFL213-08). We are grateful for the suggestions and comments made by 3 anonymous reviewers in an early version of the manuscript.

\section{LITERATURE CITED}

Alós J, Arlinghaus R (2013) Impacts of partial marine protected areas on coastal fish communities exploited by recreational angling. Fish Res 137:88-96

Alós J, Cabanellas-Reboredo M, Lowerre-Barbieri S (2012) Diel behaviour and habitat utilisation by the pearly razorfish during the spawning season. Mar Ecol Prog Ser 460:207-220

Bianchi CN (2007) Biodiversity issues for the forthcoming tropical Mediterraneansea. In: Relini G, Ryland J (eds) Biodiversity in enclosed seas and artificial marine habitats. Proceedings of the 39th European Marine Biology Symposium, Genoa, Italy, 21-24 July 2004. Springer, Dordrecht, $\mathrm{p}$ 7-21

Cremen MCM, Huisman JM, Marcelino VR, Verbruggen H (2016) Taxonomic revision of Halimeda (Bryopsidales, Chlorophyta) in southwestern Australia. Aust Syst Bot 29:41-54

Davis BC, Fourqurean JW (2001) Competition between the tropical alga, Halimeda incrassata, and the seagrass, Thalassia testudinum. Aquat Bot 71:217-232

Galil BS, Marchini A, Occhipinti-Ambrogi A, Minchin D, Narščius A, Ojaveer H, Olenin S (2014) International arrivals: widespread bioinvasions in European Seas. Ethol Ecol Evol 26:152-171

García Molinos J, Halpern BS, Schoeman DS, Brown CJ and others (2016) Climate velocity and the future global redistribution of marine biodiversity. Nat Clim Change 6: 83-88

Guiry MD, Guiry GM (2016) AlgaeBase. World-wide electronic publication, National University of Ireland, Galway. www.algaebase.org (accessed 27 June 2016)

Hillis-Colinvaux L (1980) Ecology and taxonomy of Halimeda: primary producer of coral reefs. In: Blaxter JHS, Russell FS, Maurice Y (eds) Advances in marine biology, Book Vol 17. Academic Press, New York, NY, p $1-327$

Hoffman R (2014) Alien benthic algae and seagrasses in the Mediterranean Sea and their connection to global warming. In: Goffredo S, Dubinsky Z (eds) The Mediterranean Sea: its history and present challenges. Springer, Dordrecht

Littler D, Littler M (2000) Caribbean reef plants. OffShore Graphics, Washington, DC

Multer HG (1988) Growth rate, ultrastructure and sediment contribution of Halimeda incrassata and Halimeda monile, Nonsuch and Falmouth Bays, Antigua, W.I. Coral Reefs 6:179-186

Ojaveer H, Galil BS, Minchin D, Olenin S and others (2014) Ten recommendations for advancing the assessment and management of non-indigenous species in marine eco- 
systems. Mar Policy 44:160-165

Poloczanska ES, Brown CJ, Sydeman WJ, Kiessling W and others (2013) Global imprint of climate change on marine life. Nat Clim Change 3:919-925

R Core Team (2015) R: a language and environment for statistical computing. R Foundation for Statistical Computing, Vienna. https://www.R-project.org/

Rius M, Clusella-Trullas S, McQuaid CD, Navarro RA and others (2014) Range expansions across ecoregions: interactions of climate change, physiology and genetic diversity. Glob Ecol Biogeogr 23:76-88

Targett NM, Targett TE, Vrolijk NH, Ogden JC (1986) Effect of macrophyte secondary metabolites on feeding preferences of the herbivorous parrotfish Sparisoma radians. Mar Biol 92:141-148

Van Tussenbroek BI, Van Dijk JK (2007) Spatial and temporal variability in biomass and production of psammophytic Haliemda incrassata (Bryopsidales, Chlorphyta) in a Caribbean reef lagoon. J Phycol 43:69-77

Verbruggen H, De Clerck O, N'Yeurt ADR, Spalding $H$, Vroom PS (2006) Phylogeny and taxonomy of Halimeda

Editorial responsibility: Just Cebrian, Dauphin Island, Alabama, USA incrassata, including descriptions of $H$. kanaloana and $H$. heteromorpha spp. nov. (Bryopsidales, Chlorophyta). Eur J Phycol 41:337-362

Verbruggen $\mathrm{H}$, Tyberghein L, Pauly $\mathrm{K}$, Vlaeminck $\mathrm{C}$ and others (2009) Macroecology meets macroevolution: evolutionary niche dynamics in the seaweed Halimeda. Glob Ecol Biogeogr 18:393-405

Vergés A, Steinberg PD, Hay ME, Poore AGB and others (2014) The tropicalization of temperate marine ecosystems: climate-mediated changes in herbivory and community phase shifts. Proc R Soc B 281:20140846

Wefer G (1980) Carbonate production by algae Halimeda, Penicillus and Padina. Nature 285:323-324

Wirtz P, Kaufmann M (2005) Pfennigalgen: neu für Madeira und den Ostatlantik: Halimeda incrassata. Das Aquarium 431:48-50

Zenetos A, Gofas S, Verlaque M, Cinar ME and others (2010) Alien species in the Mediterranean Sea by 2010. A contribution to the application of European Union's Marine Strategy Framework Directive (MSFD). Part I. Spatial distribution. Mediterr Mar Sci 11:381-493

Submitted: May 10, 2016; Accepted: Augsust 6, 2016

Proofs received from author(s): Sepember 26, 2016 